\title{
İdrar Kültürlerinden İzole Edilen Bakteriler ve Antibiyotik Duyarlılıkları
}

\author{
Antibiotic Susceptibility of Bacteria Isolated from Urine Cultures
}

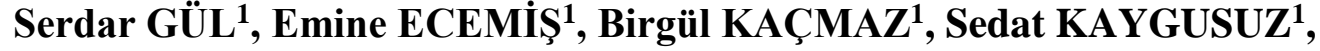 \\ Ergin AYAŞLIOĞLU', Dilek KILIÇ¹ \\ ${ }^{1}$ Kırıkkale Üniversitesi Enfeksiyon Hastalıkları ve Klinik Mikrobiyoloji A.D., KIRIKKALE
}

\begin{abstract}
ÖZET
Üriner sistem enfeksiyonları, toplum kökenli ve sağlık bakımı ile ilişkili enfeksiyonlar arasında en sık görülen enfeksiyondur. Üriner enfeksiyonlarda tedavi genellikle ampirik olarak başlandığı için etkenlerin ve antibiyotik duyarlılık paternlerinin bilinmesi tedavi başarısı için önemlidir. Bu çalıșmada Kırıkkale Üniversitesi Tıp Fakültesi Hastanesi Enfeksiyon Hastalıkları ve Klinik Mikrobiyoloji Laboratuarında Şubat 2013 -Şubat 2014 tarihleri arasında idrar kültürlerinden izole edilen bakteriler ve bu bakterilerin antibiyotik duyarlılıkları değerlendirilmiştir. İdrar kültüründe üreme saptanan hastalar antibiyotik kullanımı ve/veya hastanede yatış öyküsüne göre iki gruba ayrılmıştır. Grup 1, antibiyotik kullanımı olmayan ve/veya hastanede yatış öyküsü bulunmayan; grup 2, antibiyotik kullanımı olan ve/veya hastanede yatış öyküsü bulunan hastalardan oluşturulmuştur. Bakteri tanımlanmasında ve antibiyotik duyarlılıklarının saptanmasında Vitek 2 otomatize sistem kullanılmıştır. Toplam 118 bakteri çalışmaya alınmıştır. Birinci grup 45 ve ikinci grup 73 bakteri mevcuttu. Sonuç olarak; her iki grupta da en sık izole edilen bakteri Escherichia coli olmakla birlikte iki grup arasında etken ve duyarlılık sonuçları bakımından anlamlı farklılıklar saptanmıştır.
\end{abstract}

Anahtar Kelime: Üriner enfeksiyon, tedavi, antibiyotik duyarlılıkları

\begin{abstract}
Urinary tract infections are the most common infections among community acquired and health care related infections. Hence treatment is usually given empirically, it is important to know the pathogens and the antibiotic susceptibility patterns of these pathogens in urinary tract infections for the success of treatment. In this study the bacteria isolated from urine samples in the Infectious Diseases and Clinical Microbiology Laboratory of Kirikkale Univercity Faculty of Medicine Hospital at February 2013 February 2014 and antibiotic susceptibility patterns of these bacteria were evaluated. The patients were separated to two groups according to their history of hospitalisation and/or antibiotic usage. Group 1 was composed of patients with no history of hospitalization and/or antibiotic usage and group 2 was composed of patients with history of hospitalization and/or antibiotic usage. Vitek 2 automatized system was used for the definition and the detection of antibiotic susceptibility patterns of bacteria. One hundred and eighteen bacteria were included in the study. Fourty five bacteria were in group 1 and 73 bacteria were in group 2. In conclusion; while Escherichia coli was the most common isolate, there were significant differences among the pathogens and the antibiotic susceptibilitty patterns between two groups.
\end{abstract}

Keywords: Urinary infection, treatment, antibiotic susceptibility
Yazıșma Adresi / Correspondence: Serdar GÜL

KÜ Tıp Fakültesi, Enfeksiyon Hast. ve Klinik Mikr. A.D, KIRIKKALE

E-mail: serdarguul@mynet.com 


\section{GíRiş}

Üriner sistem enfeksiyonları, toplum kökenli enfeksiyonlar ve sağlık bakımı ile ilişkili enfeksiyonlar arasında en sik görülen enfeksiyonlardır. Akut enfeksiyonlarda en s1k izole edilen etken Escherichia coli (E. coli)'dir. Basit, komplike olmayan alt üriner sistem enfeksiyonlarında rutin olarak idrar kültürü önerilmemektedir. Komplike, hayatı tehdit eden ciddi üst üriner sistem enfeksiyonlarında da, idrar kültürleri alınıp sonuçları beklenmeden antibakteriyel tedavi ampirik olarak başlanmaktadır. Ampirik tedavinin etkili olabilmesi için o bölgede en s1k gözlenen etkenlerin ve bu etkenlerin antibiyotik duyarlılıklarının bilinmesi önemlidir. Aynı zamanda ampirik tedavi seçiminde hastanın antibiyotik kullanım öyküsünün olması ve/veya hastanede yatış öyküsünün bulunması gibi faktörler de göz önünde bulundurulmalıdır. Bakterilerin antibiyotiklere karşı duyarlılıkları bölgesel farklılıklar gösterebildiği gibi aynı bölgede zaman içerisinde de değişiklikler ortaya çıkabilmektedir (1-5). $\mathrm{Bu}$ çalışmada laboratuvarımızda idrar örneklerinden izole ettiğimiz bakterileri, bakterilerin antibiyotik duyarlılıklarını, hastaya ait antibiyotik kullanımı ve/veya hastanede yatış öykülerini inceleyip ampirik antibiyotik önerilerini oluşturmayı amaçladık.

\section{GEREÇ VE YÖNTEM}

\section{Kırıkkkale Üniversitesi Tıp Fakültesi Hastanesi} Enfeksiyon Hastalıkları ve Klinik Mikrobiyoloji Laboratuvarı'na Şubat 2013 ve Şubat 2014 tarihleri arasında gelen idrar örneklerinden izole edilen bakteriler çalışmaya alınmıştır. Hastaların antibiyotik kullanım ve hastanede yatış öyküsü sorgulanmıştır. Bakteri tiplendirmesi ve antibiyotik duyarlılıkları Vitek version 2,0 (Biomerieux, Fransa) otomatize sistem ile çalışılmıştır.

\section{BULGULAR}

Çalışmaya toplam 118 bakteri izolatı dâhil edildi. İzole edilen bakteriler iki gruba ayrıldı. Birinci grupta son altı ay içerisinde antibiyotik kullanımı ve/veya hastaneye yatışı olmayan hastalardan izole edilen bakteriler yer alırken son altı ay içerisinde antibiyotik kullanımı olan ve/veya hastaneye yatışı olan hastalardan izole edilen bakteriler ikinci gruba dâhil edildi. Birinci grupta 45 izolat, ikinci grupta 73 izolat mevcuttu ve bu izolatların dağılımı Tablo 1'de gösterilmiştir.

Tablo 1. Gruplara göre etkenlerin dağılımı ve oranları

\begin{tabular}{lcc}
\hline ETKEN & $\begin{array}{c}\text { Grup 1 } \\
\mathrm{n}(\%)\end{array}$ & $\begin{array}{c}\text { Grup 2 } \\
\mathrm{n}(\%)\end{array}$ \\
\hline E. coli & $33(73,4)$ & $44(60,3)$ \\
K. pneumonia & $7(15,6)$ & $14(19,2)$ \\
E. cloacae & $2(4,4)$ & - \\
P. aeruginosa & $1(2,2)$ & $6(8,2)$ \\
S. saprophyticus & $1(2,2)$ & - \\
S. agalactiae & $1(2,2)$ & - \\
P. mirabilis & - & $3(4,1)$ \\
A. baumannii & - & $2(2,8)$ \\
Enterococcus spp & - & $2(2,8)$ \\
E. cloacae & - & $1(1,3)$ \\
M. morganii & - & $1(1,3)$ \\
\hline Toplam & $45(100)$ & $73(100)$ \\
\hline
\end{tabular}

Birinci gruptaki bakterilerde tür ayrımı yapmadan amoksisilin/klovulonat'a $\% 22,2$, sefuroksime $\% 15,5$, seftriaksona $\% 8,8, \quad$ siprofloksasine $\% 15,5$ ve trimetoprim-sulfametoksazole karşı \%20 direnç saptanmıştır (Tablo 2).

İkinci gruptaki bakterilerde tür ayrımı yapmadan amoksisilin/klovulonata ve seftriaksona \%74, sefuroksime $\% 76,7$, siprofloksasine $\% 67$, trimetoprimsulfametoksazole \%48 ve meropeneme karşı \% 0.95 direnç saptanmıştır. İkinci gruptaki bakterilerin antibiyotiklere direnç oranları da Tablo 3'te gösterilmiştir. 
Tablo 2: Birinci gruptaki bakterilerin direnç oranları

\begin{tabular}{|c|c|c|c|c|c|c|}
\hline & $\begin{array}{l}\text { AMC } \\
\mathrm{n}(\%)\end{array}$ & $\begin{array}{c}\text { SEF } \\
\mathrm{n}(\%)\end{array}$ & $\begin{array}{l}\text { CRO } \\
\mathrm{n}(\%)\end{array}$ & $\begin{array}{c}\text { CİP } \\
\mathrm{n}(\%)\end{array}$ & $\begin{array}{l}\text { SXT } \\
\text { n (\%) }\end{array}$ & $\begin{array}{l}\text { AMP } \\
\mathrm{n}(\%)\end{array}$ \\
\hline E.coli $(\mathrm{n}: 33)$ & $6(18,2)$ & $1(3)$ & $1(3)$ & $6(18,2)$ & $7(21,2)$ & \\
\hline K.pneumonia (n:7) & 0 & $2(28,6)$ & $1(14,3)$ & 0 & $1(14,3)$ & - \\
\hline E.cloacae (n:2) & $2(100)$ & $2(100)$ & 0 & 0 & 0 & - \\
\hline P.aeruginosa (n:1) & $1(100)$ & $1(100)$ & $1(100)$ & $1(100)$ & $1(100)$ & - \\
\hline S.saprophyticus (n:1) & $1(100)$ & $1(100)$ & $1(100)$ & 0 & 0 & - \\
\hline S.agalactiae (n:1) & 0 & - & - & 0 & 0 & 0 \\
\hline
\end{tabular}

Tablo 3: İkinci gruptaki bakterilerin direnç oranları.

\begin{tabular}{lccccccc}
\hline & AMC & SEF & CRO & CIP & SXT & MER & AMP \\
\hline E.coli (n:44) & $32(72,7)$ & $35(79,5)$ & $33(75)$ & $35(79,5)$ & $21(47,7)$ & 0 & - \\
\hline K.pneumonia (n:14) & $11(78,6)$ & $11(78,6)$ & $11(78,6)$ & $7(50)$ & $11(78,6)$ & $2(14,3)$ & - \\
\hline P.aeruginosa (n:6) & $6(100)$ & $6(100)$ & $6(100)$ & $3(50)$ & - & $3(50)$ & - \\
\hline P.mirabilis (n:3) & $1(33)$ & 0 & 0 & 0 & $1(33)$ & 0 & - \\
\hline A.baumannii (n:2) & $2(100)$ & $2(100)$ & $2(100)$ & $2(100)$ & $1(50)$ & $2(100)$ & - \\
\hline Enterococcus (n:2) & - & - & - & $1(50)$ & - & - & $1(50)$ \\
\hline E.cloacae (n:1) & $1(100)$ & $1(100)$ & $1(100)$ & $1(100)$ & $1(100)$ & 0 & - \\
\hline M.morganii (n:1) & $1(100)$ & $1(100)$ & $1(100)$ & 0 & 0 & 0 & - \\
\hline K1saltmalar: & \multicolumn{2}{l}{ amoksisilin/klavulonat (AMC); sefuroksim (SEF); seftriakson (CRO); siprofloksasin (CIP); } \\
trimetoprim-sulfametoksazol (SXT); ampisilin (AMP); meropenem (MER)
\end{tabular}

Birinci grupta izole edilen E. coli suşlarından bir tanesinde (\% 3), K. pneumonia suşlarından bir tanesinde $(\% 14,3)$ genişletilmiş spektrumlu betalaktamaz (GSBL) pozitifliği tespit edilirken ikinci gruptaki E.coli suşlarının 32 'sinde $(\% 72,7), \quad K$. pneumonia suşlarının da 11 'inde $(\% 78,6)$ GSBL pozitifliği tespit edilmiştir.

\section{TARTIŞMA}

Üriner sistem enfeksiyonları, toplum kökenli ve sağlık bakımı ile ilişkili enfeksiyonlar arasında en sık görülen enfeksiyondur $(1,2,5)$. Üriner sistem enfeksiyonlarının \% 95'ten fazlası, tek bir bakteri türüne bağlı olarak gelişir ve en sik izole edilen etken E. coli'dir. Tekrarlayan üriner sistem enfeksiyonlarında özellikle de üriner sistemde yapısal anomaliler mevcutsa, Proteus, Pseudomonas, Klebsiella, Enterobacter spp, ayrica stafilokoklar ve enterokoklar daha sik etken olarak karşımıza çıkmaktadır. Hastanede yatan veya uzun süre sağlık bakımı alan, özellikle de üriner kateteri olan hastalarda üriner sistemin bakteri florası değişmekte, Proteus, Klebsiella, Enterobacter, Pseudomonas, Enterococcus spp, gibi daha dirençli olabilen bakterilerin görülme sıklığg $\operatorname{artmaktadır}(1,6)$. Ülkemizden yapılan bir çok çalışmada da üriner enfeksiyon etkenleri arasında en sık izole edilen bakteri yaklaşık \% 50-90 ile E. coli iken, (2, 7-10) bizim çalışmamızda da benzer olarak en sık E. Coli izole edildi. Ancak hastanede yatış öyküsü olan hastalarda Klebsiella pneumonia, Pseudomonas aeruginosa ve 
Acinetobacter baumanni gibi direnç potansiyeli fazla olan bakteriler daha sık izole edildi.

Ülkemizde idrardan izolen E. coli suşlarının direnç oranlarına baktığımızda ayaktan hastalarda bu oranın kinolonlar için \%7-39, trimetoprim-sulfametoksazol için \%26-43, amoksisilin/klavulonat için \%11-72 arasında değiştiğini görmekteyiz (2, 5, 10-12). Bizim çalışmamızda da $E$. coli için siprofloksasin direnci birinci grupta \%18,2 iken ikinci grupta bu oran \%79,5'e çıkmaktadır. Aynı şekilde birinci grupta $\% 21,2$ olan trimetoprim-sulfametoksazol direnci de ikinci grupta $\% 47,7$ olarak tespit edilmiştir.

Üriner sistem enfeksiyonlarında özellikle $E$. coli ve $K$. pneumonia suşlarında GSBL üretimi, tedavi açısından olumsuz sonuçlar ortaya çıkarmaktadır. Ülkemizde üriner enfeksiyon etkeni olan E. coli izolatlarında \%526 arasında GSBL pozitifliği saptanabilmektedir (2, 12). Bizim çalışmamızda da E. coli suşlarında GSBL pozitifliği birinci grupta sadece \% 3 iken bu oran ikinci grupta \%72,7’ye çıkmıştır.

Üriner sistem enfeksiyonlarının tedavisinde kinolonlar, sefalosporinler, aminoglikozitler ve trimetoprimsulfametoksazol gibi birçok antibiyotik başarı ile kullanılabilmektedir. Ancak hücre duvarı üzerine etkili antibiyotiklerin üriner sistemden bakteriyi eradike edebilmede daha az etkin olduğunu gösteren kanıtlar olduğu için tedavide öncelikle kinolonların, aminoglikozitlerin veya trimetoprimsulfametoksazolün tercih edilmesi önerilmektedir $(1,13,14)$. Ayaktan, komplike olmayan üriner enfeksiyonların tedavisinde mutlaka hızlı etkili bakterisidal antibiyotiklerin kullanılması gerekmezken, özellikle hastanede yatan ağır hayatı tehdit eden üriner enfeksiyonların tedavisinde ampirik tedavi başlanırken etki spektrumunda hiçbir boşluk bırakılmaması, tüm dirençli bakterileri de kapsayacak şekilde tedavi planlanması önerilmektedir. İzole edilen bakterinin antibiyotik duyarlılık paterni tespit edildiğinde daha dar spektrumlu ve daha düşük maliyetli bir tedaviye geçilmesi (deeskalasyon) daha uygundur (1).

Yetişkinlerde komplike olmayan alt üriner sistem enfeksiyonlarının tedavisinde eğer trimetoprimsulfametoksazole karşı direnç oranı $\leq \% 20$ ise trimetoprim-sulfametoksazol kullanımı önerilmektedir ancak diğer antibiyotiklere karşı böyle bir eşik değeri tespit edilememiştir (1). Bizim çalışmamızda birinci grup bakterilerde trimetoprim-sulfametoksazole toplam direnç \%20 olduğu için komplike olmayan sistit tedavisinde son altı ayda hastaneye yatışı ve/veya antibiyotik kullanımı olmayan hastalarda trimetoprimsulfametoksazol uygun bir seçenek gibi görünmektedir. Yaklaşık \%15'lik direnç oranları ile bu hasta grubunda kinolon veya ikinci kuşak sefalosporinler de tedavide kullanılabilecek antibiyotiklerdir.

Akut piyelonefrit tedavisinde ampirik olarak kinolonlar, beta-laktam antibiyotikler ve aminoglikozitler başarı ile kullanılabilmektedir. Ĕ̆er kinolonlara karşı direnç oranı $<\% 10$ ise ampirik tedavide siprofloksasin uygun bir seçenektir (1). Bizim çalışmamızda siprofloksasin direnci birinci grupta $\% 15,5$ iken, ikinci grupta bu oran \%67 olarak tespit edilmiştir ve kinolonlar piyelonefrit tedavisinde özellikle de hastaneye yatış öyküsü olan hastalarda uygun bir seçenek gibi görünmemektedir. Piyelonefritin ampirik tedavisinde birinci gruptaki hastalar için \%8.8 direnç oranı ile seftriakson uygun bir seçenek olabilir. Ancak ikinci gruptaki hastalardan izole edilen bakteriler, karbapenem haricindeki antibiyotiklere karşı yüksek oranda dirençli oldukları için, hastanede gelişen, uzun süreli sağlık bakımı görmüş ve antibiyotik kullanım öyküsü olan hastalarda gelişecek ciddi ve hayatı tehdit eden üriner sistem enfeksiyonlarının tedavisinde ampirik olarak karbapenem başlamak, antibiyotik duyarlılık sonuçlarına ulaşılınca gerekirse tedavide deeskalasyon yapmak daha uygun olacaktır. 
İdrardan izole edilen bakterilerin ve bu bakterilerin antibiyotik duyarlılık paternlerinin bölgeden bölgeye ve aynı bölgede zaman içerisinde değişiklik gösterdiği bilindiği için sağlık kuruluşlarında bu konudaki çalışmaların belirli zaman aralıkları ile tekrarlanmasının faydalı olacağını düşünmekteyiz.

\section{KAYNAKLAR}

1. Sobel JD, Kaye D. Urinary Tract Infections. In: Mandell GL, Bennett JE, Dolin R, eds. Principles and Practice of Infectious Diseases. 7th ed. Philadelphia: Churchill Livingstone, 2010: 957-83.

2. Arman D, Agalar C, Dizbay M, Tunçcan ÖG, Keten DT, Aygün G, Tünger Ö, Demirtürk N, İnan D, Özakın C, Bayındır Y, Akbulut A, Bakır M, Köksal İ, Özinel MA, Öztoprak N, Aktaş E, Alpay Y. Birinci Basamak Sağlık Merkezlerinde Toplum Kökenli Alt Üriner Sistem Enfeksiyonları: Etkenler ve Antimikrobiyal Duyarlılıkları. Mediterr J Infect Microb Antimicrob. 2012; 1: 10.

3. Falagas ME, Polemis M, Alexiou VG, MariniMastrogiannaki A, Kremastinou J, Vatopoulos AC. Antimicrobial resistance of Escherichia coli urinary isolates from primary care patients in Greece. Med Sci Monit. 2008; 14: CR75-79.

4. Savaş L, Güvel S, Turunç T, Savaş N, Arslan H. Toplum kökenli ve nazokomiyal üriner sistem enfeksiyonu etkenleri ve antibiyotik duyarlılıklarının karşılaştırılması. Türk Üroloji Dergisi. 2003; 29: 95-100.

5. Terek EG, Başoğlu TM. Bir üniversite hastanesine gönderilen idrar kültürlerinde üreyen izolatların dağılımı ve antimikrobiyal duyarlılık profilinin incelenmesi. Ege Tıp Dergisi. 2013; 52(3): 136-40.

6. Gaynes R, Edwards JR. National Nasocomial Infections Surveillance System. Overview of nasocomial infections caused by Gram-negative bacilli. Clin Infect Dis. 2005; 41: 848-854.
7. Yetkin G, Kuzucu Ç, Çalışkan A. İdrarda Üreyen Escherichia coli’lerin Geniş Spektrumlu Beta Laktamazlar Yönünden İrdelenmesi. İnönü Üniversitesi Tıp Fakültesi Dergisi. 2006; 13(4): 249-252.

8. Saraçoğlu KT, Fidan V, Pekel Ö, Saraçoğlu A, Kalkandelen S, Arpalı E. İdrar kültürlerinde izole edilen bakterilerin antibiyotik duyarlılıkları. J Clin Exp Invest. 2013; 4(3): 356-359.

9. Ağca H. İdrar Örneklerinden İzole Edilen Bakteriler ve Antibiyotiklere Duyarlılıkları. Kocatepe Tip Dergisi. 2011; 12(2): 95-100.

10. Yılmaz R, Karaaslan E, Özçetin M, Arslan B, Kılınç M, Kazancı NÖ. Çocuklarda idrar yolları enfeksiyonu etkenleri ve antibiyotik duyarlılıkları. Çağdaş Tıp Dergisi. 2012; 2(1): 17-21.

11. Kaçmaz B, Aksoy A, Sultan N. İdrar örneklerinden izole edilen Escherichia coli izolatlarında oral antibiyotiklere karşı direncin araştırılması. Türk Hijyen ve Deneysel Biyoloji Dergisi. 2007; 64(1): $11-15$.

12. Deveci Ö, Yula E, Tekin A. İdrar kültürlerinden izole edilen Escherichia coli sușlarında betalaktamaz sıklığg ve antibiyotik direnci. J Clin Exp Invest. 2010; 1(3): 182-86.

13. Warren JW, Abrutyn E, Hebel JR, Johnson JR, Schaeffer AJ, Stamm WE. Guidelines for antimicrobial treatment of uncomplicated acute bacteriel cystitis and acute pyelonephritis in women. Infectious Diseases Society of America (IDSA). Clin Infect Dis. 1999; 29: 745-58.

14. Hooton TM. The current management strategies for community-acquired urinary tract infection. Infect dis Clin North Am. 2003; 17: 303-322. 